\title{
The Gustavia clade (Lecythidaceae) in Central America: a new record of Gustavia sessilis and a key to its species
}

\section{El clado Gustavia (Lecythidaceae) en América Central: un nuevo registro de Gustavia sessilis y una clave para sus especies}

ActaBotanica Mexicana

\author{
Juvenal E. Batista Guerra',2 (D), Orlando O. Ortiz' (iD)
}

\begin{abstract}
:
Background and Aims: Gustavia sessilis is a neotropical tree, belonging to the Lecythidaceae family, until now known from the Colombian Chocó region only. In this paper, we report $G$. sessilis for the first time for Central America.

Methods: Central American specimens of G. sessilis were collected in 2019 from the Darién Province (eastern Panama). Plant identifications were confirmed by comparing collected specimens with those identified earlier and housed in the MO, PMA, SCZ and UCH herbaria. Type specimens were examined by consulting the JSTOR Global Plants database. The estimations of the conservation status were made based on the criteria of the IUCN. Key results: The record of G. sessilis for Central America is presented, based on a collection made from eastern Panama (Darién Province). Photographs, taxonomic comments, and conservation notes are provided. Additionally, a key for the Central American Gustavia species is included.

Conclusions: The distribution of G. sessilis now ranges from Bahía Piñas, Darién Province, Panama to the Condoto river, Chocó region, Colombia, highlighting the importance of the Chocó Panama-Colombia region for the conservation of biodiversity, since it could act as a natural corridor for species. Taking into account the small number of records and the restricted natural range of this species, we recommend considering $G$. sessilis as an endangered species.
\end{abstract}

Key works: Chocó region, Darién, endangered species, Flora of Colombia, Flora of Panama, membrillo.

\section{Resumen:}

Antecedentes y Objetivos: Gustavia sessilis es un árbol neotropical perteneciente a la familia Lecythidaceae, hasta la fecha conocido únicamente de la región colombiana del Chocó. En este artículo, se registra por primera vez G. sessilis para Centroamérica.

Métodos: Los especímenes centroamericanos de G. sessilis se recolectaron en la Provincia de Darién (oriente de Panamá), durante el año 2019. La identificación de las plantas se confirmó comparando los especímenes recolectados con las colecciones alojadas en los herbarios MO, PMA, SCZ y UCH. Los especímenes tipo se examinaron consultando la base de datos de JSTOR Global Plants. La estimación del estado de conservación se realizó con base en los criterios de la UICN.

Resultados clave: El registro de G. sessilis en Centroamérica se presenta con base en una colección realizada en el Este de Panamá (Provincia de Darién). Se proporcionan fotografías, comentarios taxonómicos y notas sobre la conservación de esta especie. Además, se incluye una clave de las especies centroamericanas de Gustavia.

Conclusiones: La distribución de G. sessilis se extiende desde Bahía Piñas, Provincia de Darién, Panamá hasta el río Condoto, región de Chocó, Colombia, lo que resalta la gran importancia de la región de Chocó Panamá-Colombia para la conservación de la biodiversidad, ya que podría actuar como corredor natural de especies. Teniendo en cuenta el escaso número de localidades y el restringido rango natural de esta especie, recomendamos considerar a G. sessilis como una especie en peligro de extinción.

Palabras clave: Región del Chocó, Darién, especie en peligro de extinción, Flora de Colombia, Flora de Panamá, membrillo.

${ }^{1}$ Universidad de Panamá, Herbario PMA, Estafeta Universitaria, Apartado 3366, Panamá City, Panama. ${ }^{2}$ Author for correspondence: batistajuvenal29@gmail. com
Received: April 3, 2020. Reviewed: May 6, 2020

Accepted by Marie-Stéphanie Samain: June 22, 2020 Published Online first: July 2, 2020.

Published: Acta Botanica Mexicana 127 (2020).
To cite as: Batista Guerra, J. E. and O. O. Ortiz. 2020. The Gustavia clade (Lecythidaceae) in Central America: a new record of Gustavia sessilis and a key to its species. Acta Botanica Mexicana 127: e1708. DOI: 10.21829/abm127.2020.1708

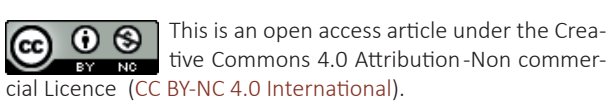
cial Licence (CC BY-NC 4.0 International).
e-ISSN: 2448-7589 


\section{Introduction}

The Gustavia clade is a monophyletic group of Lecythidaceae that includes only the neotropical genus Gustavia L. (Mori et al., 2015; Vargas and Dick, 2020). This genus comprises small to medium sized trees (up to $30 \mathrm{~m}$ tall), with petiolate or sessile leaves, cauline, axillary suprafoliar or terminal inflorescences (solitary or racemose), with pedicels subtended by a single bract and two opposite or sub-opposite bracteoles inserted along the length of the pedicel (Prance and Mori, 1979). The androecia of all species of Gustavia are actinomorphic, the filaments arise from the rim of the staminal tube and are much longer than those of any other neotropical Lecythidaceae. It is the only genus of the family that has apically poricidal anthers, which suggest buzz pollination (Mori and Boeke in Mori, 1987). The fruits are indehiscent and are usually globose in shape (Mori et al., 2015).

The currently used infrageneric classification of Gustavia by Prance and Mori (1979) grouped the genus into three sections, based on their floral and fruit morphological differences: Hexapetala S.A. Mori, Grandibracteata S.A. Mori and Gustavia. However, additional molecular studies are required to test the monophyly of this sectional classification. Section Hexapetala is characterized by having leaf blades usually less than $30 \mathrm{~cm}$, never more than $50 \mathrm{~cm}$ long, flowers with six calyx lobes and six petals, hypanthium with strongly developed costae persisting in the fruit, and calyx lobes with an adaxial inverted "Y shaped" thickening. Section Grandibracteata consists of monocaulous or fewbranched trees, inflorescences suprafoliar, subtended by the terminal whorl of large, tightly compacted leaves, pedicels subtended by a large bract and with two large bracteoles inserted just below the hypanthium, without thickened calyx lobes and costae on the hypanthium, calyx lobes without adaxial "Y-shaped" thickenings. Members of section Gustavia comprise few-branched to many-branched trees with cauline inflorescences (axillary or suprafoliar), when suprafoliar, not subtended by a terminal whorl of large compacted leaves, pedicels subtended by a small, scalelike, usually caducous bract or normal leaves and with two variously inserted, scale-like bracteoles.

During recent botanical explorations conducted in poorly explored areas identified by Ortiz et al. (2019), specimens of G. sessilis S.A. Mori (sect. Grandibracteata) were collected, which represent the first records of the species in Central America. This species was previously only known from two collections made in the Colombian Chocó (Prance and Mori, 1979; TROPICOS, 2020). Photographs, taxonomic comments, conservation notes and a key for Central American Gustavia species are provided.

\section{Material and Methods}

Central American specimens of $G$. sessilis were collected in 2019 from the Darién Province (eastern Panama). Plant identifications were confirmed by comparing collected specimens with those identified earlier and housed in the University of Panama (PMA) and Missouri Botanical Garden (MO) herbaria. In addition, type specimens of G. sessilis were examined by consulting the JSTOR Global Plants database (Gallagher, 2010; JSTOR, 2020).

The evaluation of its conservation status was based on the criteria of the IUCN (2001), using the parameters of number of locations (the number of geographically or ecologically distinct areas of occurrence), extent of occurrence (criterion B1: the spatial spread of the areas currently occupied by a taxon) and area of occupancy (criterion B2: a scaled metric that represents the area of suitable habitat currently occupied by a taxon). The extent of occurrence and area of occupancy values were computed using the GeoCAT software (Bachman et al., 2011), based on the information obtained from Magill et al. (2020), TROPICOS (2020), type specimens and the new records included in this work. The information on the morphological description of G. sessilis was obtained from Mori et al. (2010 onward).

\section{Results}

Gustavia sessilis S.A. Mori, Brittonia 28(3): 291-293. 1976.

Figs. 1, 2.

TYPE: COLOMBIA. Chocó, dense forest S of Río Condoto between Quebrada Guarapo and Mandinga, 120-180 m, 22-28.IV.1939, fl., E. P. Killip 35417 (holotype: US!, isotypes: BM!, COL!, NY!, WIS! photo). 


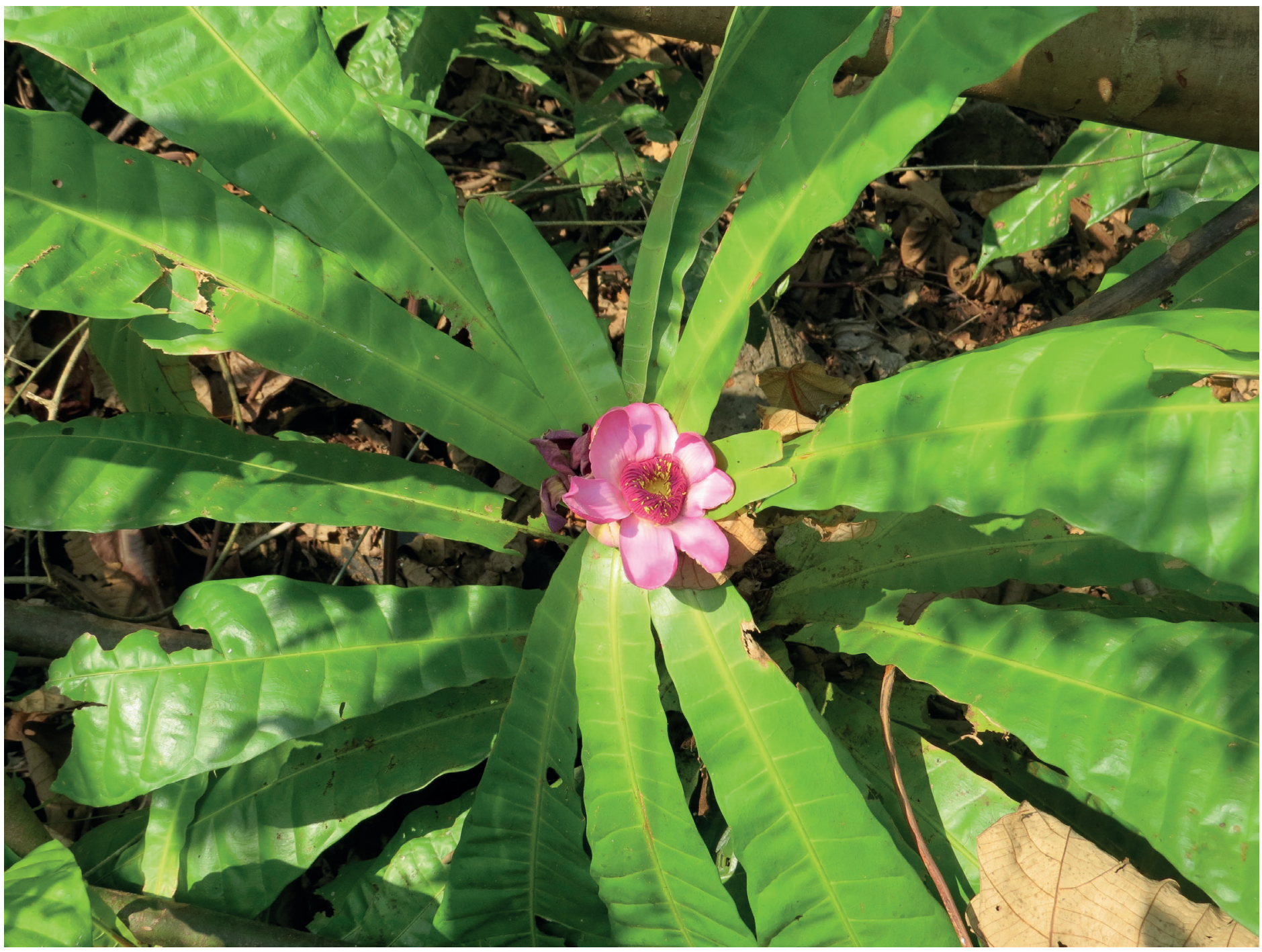

Figure 1. Gustavia sessilis S.A. Mori. Apical view of a monocaulous branch, showing the leaves forming a compact rosette, sessile oblanceolate leaf blades and a suprafoliar (terminal) inflorescence with three flowers, from Área de Manejo Especial de Bahía Piñas, Aceite, Darién, Panama. Photo credits: Orlando O. Ortiz.

Tree, $5 \mathrm{~m}$ tall, with slender trunk; leaf-bearing branches 11-14 mm diameter; leaves in a compact rosette at their apex; petiole scars touching; leaf blades sessile, oblanceolate, $71-88 \times 13-15 \mathrm{~cm}$, glabrous, chartaceous, with ca. 40 pairs of lateral veins; apices acuminate; margins entire; inflorescence terminal, racemose, puberulous, 4-5 flowered; rachis $45 \mathrm{~mm}$ long, with distinct downward-curving floral bract scars; pedicels 40-50 mm long, subtended by a single, lanceolate, parallel-veined, greenish-white bract, 75-100 × 10-25 mm, bearing directly below the hypanthium 2 oblong, acute-tipped bracteoles, 16-22 × 6-8 mm; hypanthium without costae, densely rusty-pubescent; calyx with 4 well-de- veloped, triangular lobes, $8 \times 15 \mathrm{~mm}$; corolla with 8 ovate petals, rusty-white-pubescent in bud; connate androecium base $4 \mathrm{~mm}$ high, outermost filaments $11 \mathrm{~mm}$ long, anthers $3 \mathrm{~mm}$ long; ovary without costae, densely rusty pubescent, 6-locular, stigma 6-lobed; fruits unknown.

Vernacular name: membrillo.

Distribution and habitat: from the Chocó region of Colombia and Bahía Piña region of Darién (Fig. 3). In Panama, this species is very common in the gallery forests of the Río Piña (Darién Province). 


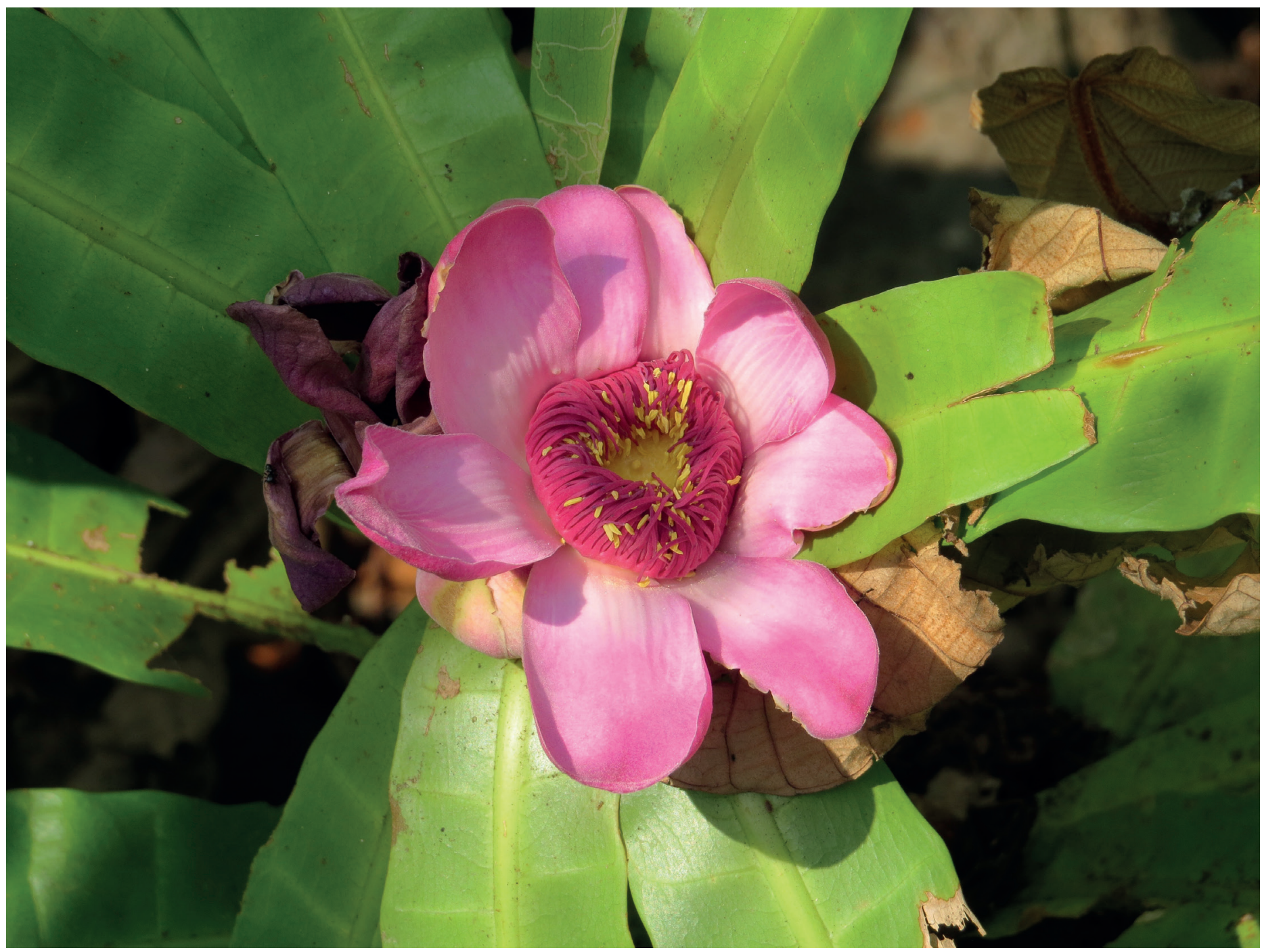

Figure 2. Gustavia sessilis S.A. Mori. Apical view of suprafoliar flower, showing its ovate petals and connate staminal ring, from Área de Manejo Especial de Bahía Piñas, Aceite, Darién, Panama. Photo credits: Orlando O. Ortiz.

Phenology: flowers have been collected in March (Panama) and April (Colombia).

Additional specimens examined: PANAMA. Darién, Área de Manejo Especial de Bahía Piñas, Aceite, $144 \mathrm{~m}$, $07^{\circ} 38^{\prime} 33^{\prime \prime} \mathrm{N}, 78^{\circ} 11^{\prime} 06^{\prime \prime} \mathrm{W}, 01 . I I .2019$, O. O. Ortiz et al. 3528 (MO, PMA).

\section{Discussion}

In the Lecythidaceae monograph by Prance and Mori (1979), eight species of Gustavia for Central America were reported, with most of them occurring in Panama. Subsequently, the taxonomic treatment for Central America by
Mori and Prance (2009) only listed seven species of Gustavia, because $G$. verticillata Miers was not included in this work; the exact reasons or justifications for the exclusion of this species were not discussed by the authors. We have reviewed the Panamanian specimen (Duke 10964, MO) of G. verticillata cited by Prance and Mori (1979), and it fits with the diagnostic characteristics of this species: suprafoliar inflorescences, markedly petiolate leaves and flowers with an entire calyx. Taking into account the aforementioned and our results, the flora of Central America now comprises nine species of Gustavia.

The Panamanian population of $G$. sessilis coincides with the morphological characteristics, habitat and ecolo- 


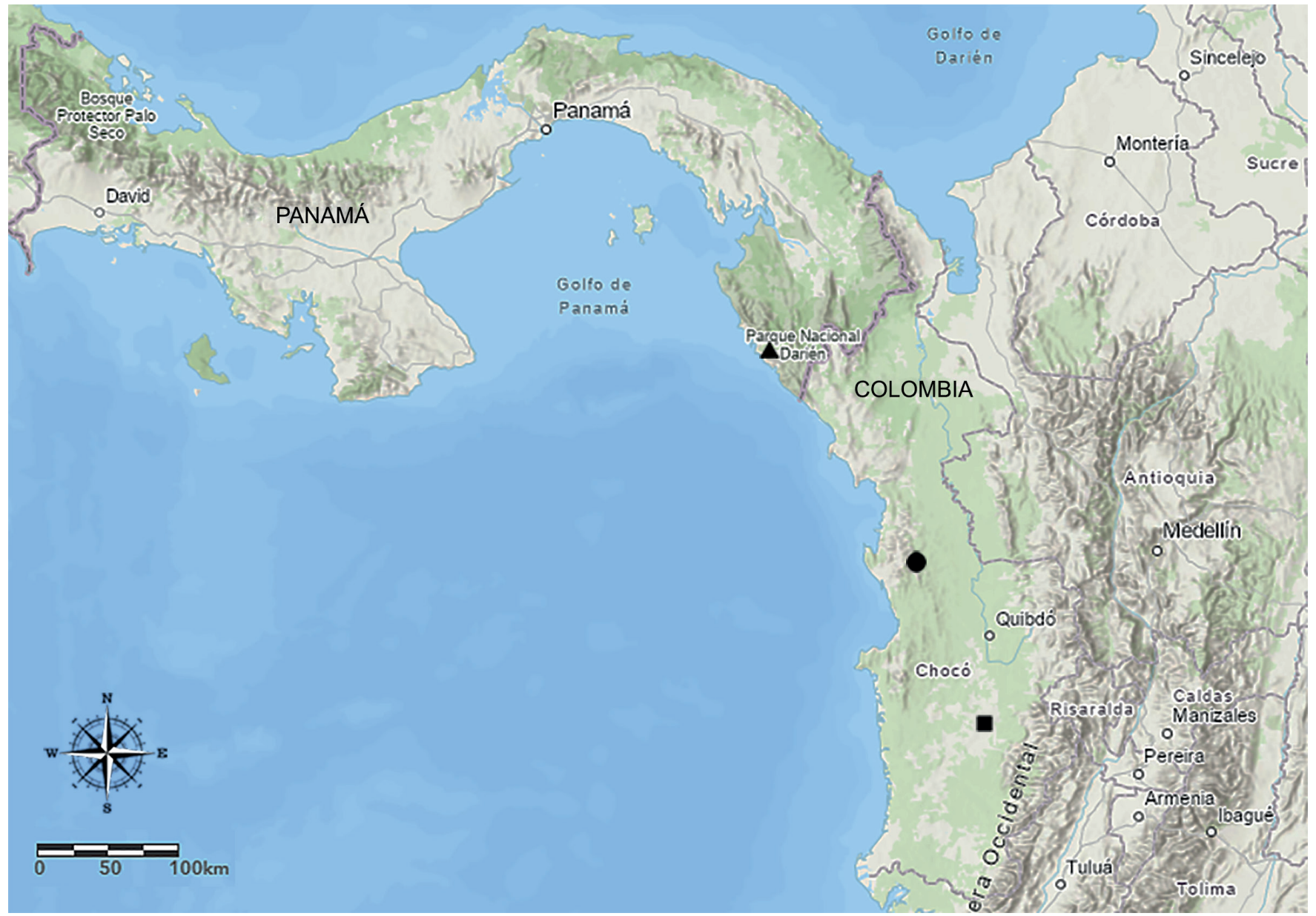

Figure 3. Map showing the distribution of Panamanian population of G. sessilis S.A. Mori from Área de Manejo Especial de Bahía Piñas, Aceite, Darién (triangle) and Colombian population from Río Condoto (square) and Parque Nacional Natural Utría (circle), Chocó.

gy of the population found in the type locality in the Colombian Chocó. This species is characterized by having sessile leaves with entire margins, flower cluster without leaf-like subtending bracts, pedicels of $40-50 \mathrm{~mm}$ long, triangular calyx lobes and an androecial tube of $4 \mathrm{~mm}$ high. Gustavia sessilis is morphologically similar to $G$. flagellata S.A. Mori, G. grandibracteata, and G. pubescens Ruiz ex O. Berg. These four species comprise a species complex (Gustavia grandibracteata complex) characterized by having unbranched or few-branched forms, monopodial stem elongation, solitary but clustered inflorescences produced from the stem above the terminal rosette of large leaves, relatively large basal floral bracts and pedicellary bracteoles, and 4 or 6 well-defined, usually ovate or broadly ovate calyx lobes (Mori, 1976). Gustavia pubescens differs from $G$. sessilis mainly by having leaf blades pilose abaxial- ly and flowers with 6 petals and sepals; G. grandibracteata can be distinguished by its markedly petiolate leaves (20$78 \mathrm{~mm}$ long) and $\mathrm{G}$. flagellata is differentiated by having leaf blades serrulate to serrate towards the apex and very widely ovate calyx lobes.

According to the IUCN Red List, this species is vulnerable VU (B1+2C) (WCMC, 1998). Currently, this species is only known from three locations and comprises an extent of occurrence of $3156 \mathrm{~km}^{2}$ and an area of occupancy of $12 \mathrm{~km}^{2}$. Taking into account that several areas of the Chocó-Darién moist forests ecoregion are devoid of protection (Sarkar et al., 2009), adding the small number of localities and the restricted natural range of this species, we recommend considering $G$. sessilis as an endangered species EN (B1(ii,iii,iv,v)+B2(ii, iii,iv,v)). 
Key of Gustavia taxa from Central America; based on Mori and Prance (2009) with modifications

1a. Leaf blades usually less than $30 \mathrm{~cm}$, never more than $50 \mathrm{~cm}$ long; flowers with 6 calyx lobes and 6 petals; hypanthium with 6 strongly developed costae or wings persisting on the fruit; calyx lobes with an adaxial, inverted "Y-shaped" thickening

1b. Leaf blades 17-136 cm long; flowers with an entire calyx or with 4 calyx lobes and 8 petals, if with 6 calyx lobes or petals then without thickened calyx lobes and costae or wings on the hypanthium; hypanthium smooth or with 4(-6) obscure costae; calyx lobes without adaxial "Y-shaped" thickenings .. 3

2a. Leaf blades $10-20 \times 3.5-7 \mathrm{~cm}$; fruits cylindrical, $25 \times$ $20 \mathrm{~mm}$; costae decurrent on pedicel; Eastern Chiriquí, Southern Veraguas in Panama and the Osa Peninsula, Costa Rica Gustavia brachycarpa S.A. Mori

2b. Leaf blades 8-20 × 4-7 cm; fruits globose, 15-20 × 17$30 \mathrm{~mm}$; costae absent or, if present, not decurrent to base; Eastern Panama and Magdalena Valley, Colombia Gustavia dubia O. Berg

3a. Monocaulous or few-branched trees; inflorescences suprafoliar, subtended by the terminal whorl of large (35-100 cm long), tightly compacted leaves; pedicels subtended by a large bract $25-115 \times 10-35 \mathrm{~mm}$ and with 2 large bracteoles $13-65 \times 6-48 \mathrm{~mm}$ inserted just below the hypanthium 4

3b. Few-branched to many-branched trees; inflorescences cauline, axillary, or suprafoliar when suprafoliar not subtended by a terminal whorl of large compacted leaves; pedicels subtended by a small, scale-like, usually caducous bract or normal leaves and with 2 variously inserted, scale-like bracteoles

4a. Leaves petiolate, petiole $20-78 \mathrm{~mm}$, leaf blades markedly serrate; flower cluster subtended by sterile leaflike bracts, these often persistent for several years, the two bracteoles on the pedicel 45-65 × 34-48 mm; Central Panama eastward into the Magdalena Valley of Colombia ............ Gustavia grandibracteata S.A. Mori

4b. Leaves sessile, leaf blades entire to serrate; flower cluster without subtending, sterile, leaf-like bracts, the two bracteoles on the pedicel 15-22 × 6-19 mm; Eastern Panama to Southern Chocó ... 5a. Leaf blades entire, $71-88 \times 13-15 \mathrm{~cm}$; flowers with pedicels 40-50 mm long; calyx lobes triangular, $8 \times 15$ $\mathrm{mm}$; connate androecium base $4 \mathrm{~mm}$ high, outermost filaments $11 \mathrm{~mm}$; Southern Chocó, Colombia and Darién (Bahía Piñas), Panama

Gustavia sessilis S.A. Mori

5b. Leaf blades serrate to serrulate towards the apex, 92$120 \times 18-33 \mathrm{~cm}$; flowers with pedicels $30-40 \mathrm{~mm}$; calyx lobes very widely ovate, $16-25 \times 23-40 \mathrm{~mm}$; connate androecium base $9 \mathrm{~mm}$ high; outermost filaments 2225 mm; Chepo, Darién, Panama and Chocó, Colombia Gustavia monocaulis S.A. Mori

6a. Inflorescences mostly arising above the leaves (suprafoliar) 7

6b. Inflorescences mostly arising among or below the leaves (axillary or cauline) 8

7a. Leaf blades oblanceolate to spathulate, 26-72 $\times$ 5-10 $\mathrm{cm}$; petioles 5-23 mm; inflorescence with 10-13 flowers; bracts 8-12 × 5-7 mm; calyx 4-lobed with broadly triangular lobes; ovary 5-6-locular; stigma 6-lobed; Barro Colorado Island, Panama

Gustavia fosteri S.A. Mori

7b. Leaf blades narrowly elliptic to oblanceolate, 16-30 $\times$ 3-6 cm; petioles 10-55 mm; inflorescence with 2-5 flowers; bracts 2-3 × 2-3 mm; calyx entire; ovary 4-locular; stigma 4-lobed; Darién, Panama and Magdalena Valley, Colombia Gustavia verticillata Miers

8a. Petioles 5-150 × 1-9 mm; largest leaf blades equal to or larger than $30 \mathrm{~cm}$ long; inflorescence axillary, suprafoliar or cauline; ovary 6-locular; Central, Eastern Panama and Northwestern Colombia Gustavia superba (Kunth) O. Berg

8b. Petioles $60-150 \times 1.5-3 \mathrm{~mm}$; largest leaf blades less than $30 \mathrm{~cm}$ long; inflorescence cauline; ovary 4-5-locular; Eastern Panama and Chocó, Colombia 9

9a. Leaf blades narrowly elliptic, length to width ratio $>4$, chartaceous, non-bullate; bracts 3-5 mm, deciduous Gustavia nana Pittier subsp. nana

9b. Leaf blades ovate or lanceolate, length to width ratio $<4$, coriaceous, bullate; bracts 5-10 mm, persistent ..... Gustavia nana Pittier subsp. rodantha (Standl.) S.A. Mori 


\section{Author contributions}

JEBG made identifications, reviewed herbarium material and performed the taxonomic key. $\mathrm{OOO}$ collected the specimens and performed the conservation assessment and taxonomic comments. Both authors contributed to the design and implementation of the research, and reviewed all versions of the manuscript.

\section{Funding}

This research was carried out with the support offered by Tropic Star Lodge (Darién), as well as with own resources.

\section{Acknowledgements}

We are very grateful to the curators of the following herbaria: PMA, MO, SCZ, and $\mathrm{UCH}$ for allowing access to their collections. The junior author is very grateful to Iván Tuñon for assistance during the field trips.

\section{Literature cited}

Bachman, S., J. Moat, A. W. Hill, J. de la Torre and B. Scott. 2011. Supporting Red List threat assessments with GeoCAT: geospatial conservation assessment tool. ZooKeys 150: 117-126. DOI: https://doi.org/10.3897/zookeys.150.2109

Gallagher, M. S. 2010. JSTOR plant science. In: Nimis, P. L. and R. V. Lebbe (eds.). Tools for Identifying Biodiversity: Progress and Problems. Edizioni Università di Trieste. Trieste, Italy. Pp. 417-418.

IUCN. 2001. The International Union for Conservation of Nature and Natural Resources Red List categories and criteria, version 3.1. http://www.iucnredlist.org/technical-documents/ categories-and-criteria/2001-categories-criteria (consulted March, 2020).

JSTOR. 2020. JSTOR Global Plants, Gustavia sessilis types. https:// plants.jstor.org/search?plantName=\%22Gustavia+sessilis\%22\&syn=1 (consulted February, 2020).

Magill, B., J. Solomon and H. Stimmel H. 2020. Gustavia sessilis S.A. Mori. Occurrence dataset. https://www.gbif.org/occurrence/1260370684 (consulted June, 2020).

Mori, S. A. 1976. New species of Gustavia (Lecythidaceae) from Panama, Colombia, and Venezuela. Brittonia 28(3): 289-297. DOI: https://doi.org/10.2307/2805790

Mori, S. A. 1987. The Lecythidaceae of La Fumée Mountain, French Guiana. Memoirs of the New York Botanical Garden 44: 137155.
Mori, S. A. and G. T. Prance. 2009. Lecythidaceae. In: Davidse, G., M. Sousa Sánchez, S. Knapp and F. Chiang Cabrera (eds.). Flora Mesoamericana 4: Cucurbitaceae a Polemoniaceae. Missouri Botanical Garden Press. St. Louis, USA. Pp. 141-163.

Mori, S. A., N. P. Smith and G. T. Prance. 2010 onward. The Lecythidaceae Pages. The New York Botanical Garden. http://sweetgum. nybg.org/science/projects/Ip/ (consulted November, 2019).

Mori, S. A., N. P. Smith, Y-Y. Huang, G. T. Prance, L. M. Kelly and C. C. Matos. 2015. Toward a Phylogenetic-based Generic Classification of Neotropical Lecythidaceae-II. Status of Allantoma, Cariniana, Couratari, Couroupita, Grias and Gustavia. Phytotaxa 203(2): 122-137. DOI: https://doi.org/10.11646/phytotaxa.203.2.2

Ortiz, O. O., R. Flores, G. McPherson, J. F. Carrión, E. Campos-Pineda and R. M. Baldini. 2019. Additions to the Flora of Panama, with comments on plant collections and information gaps. Check List 15(4): 601-627. DOI: https://doi.org/10.15560/15.4.601

Prance, G. T. and S. A. Mori. 1979. Lecythidaceae - Part I. The actinomorphic-flowered New World Lecythidaceae (Asteranthos, Gustavia, Grias, Allantoma \& Cariniana). Flora Neotropica Monograph 21: 1-270.

Sarkar, S., V. Sánchez-Cordero, M. C. Londoño and T. Fuller. 2009. Systematic conservation assessment for the Mesoamerica, Chocó, and Tropical Andes biodiversity hotspots: a preliminary analysis. Biodiversity and Conservation 18: 1793-1828. DOI: https:// doi.org/10.1007/s10531-008-9559-1

TROPICOS. 2020. Tropicos.org, Gustavia sessilis S.A. Mori. Missouri Botanical Garden. http://www.tropicos.org/Name/17900413 (consulted April, 2020).

Vargas, O. M. and C. W. Dick. 2020. Diversification History of Neotropical Lecythidaceae, an Ecologically Dominant Tree Family of Amazon Rainforest. In: Rull, V. and A. Carnaval (eds.). Neotropical Diversification: Patterns and Processes. Springer. Basel, Switzerland. Pp. 791-809. DOI: https://doi.org/10.1007/978-3030-31167-4_29

WCMC. 1998. World Conservation Monitoring Centre, Gustavia sessilis. The International Union for Conservation of Nature and Natural Resources Red List of Threatened Species 1998: e.T32118A9680987. https://doi.org/10.2305/IUCN.UK.1998. RLTS.T32118A9680987.en (consulted March, 2020). 